\title{
UM OLHAR ANTROPOLÓGICO SOBRE FATOS E MEMÓRIAS DA IMIGRAÇÃO ITALIANA
}

\author{
Maria Catarina Chitolina Zanini
}

Este artigo objetiva analisar de que forma os migrantes italianos que rumaram para a região central do estado do Rio Grande do $\mathrm{Sul}^{1}$ nas últimas três décadas do século XIX conduziram o processo colonizador, e com quais categorias sociais estabeleceram as relações entre si e com a sociedade local e nacional. Para tal, farei uso de memórias escritas por dois desses migrantes e traduzidas para publicação por seus descendentes: Julio Lorenzoni² (1863-1934), nascido em Vila Raspa, partiu da Itália com sua família em 1877, aos 14 anos, e Andrea Pozzobon (1863-19-), ${ }^{3}$ aqui chegado em 1885, já com 22 de idade e recém-casado, ambos vênetos. As memórias de Julio Lorenzoni foram traduzidas por sua filha, Arminda Lorenzoni Parreira e publicadas em 1975 quando do Centenário da Imigração Italiana no estado, sob o título Memórias de um imigrante italiano. Alguns dos textos presentes nesta obra já faziam parte do Álbum do Cinqüentenário da imigração italiana no estado e do Álbum I municipi della colonia italiana nello stato di Rio Grande do Sul (Brasile) — Bento Gonçalves (Marcon 1975:9). As memórias de Andrea Pozzobon foram publicadas em 1997 por seu neto Zolá Franco Pozzobon e receberam o título de Uma odisséia na América. Abarcam o período de vida do migrante que vai de 1884 a 1928 . As duas foram originalmente escritas em italiano e traduzidas para fins de publicação.

Tanto Lorenzoni quanto Pozzobon iniciam suas narrativas escritas em proximidade temporal ao processo migratório, salientando o quanto este foi marcante em suas existências. Suas trajetórias nas colônias também se assemelharão: serão camponeses num primeiro momento, professores no decorrer de suas vidas, membros das Sociedades de Mútuo Socorro e ocuparão cargos de destaque em suas comunidades. Andréa Pozzobon fixase em Arroio Grande, distrito de Santa Maria e ali permanece. Lorenzoni muda-se em 1884, já casado, para Bento Gonçalves, região de colonização italiana na serra gaúcha. Também farei uso das representações contidas no 
Álbum (ou "Monografia") do primeiro Cinquentenário da imigração italiana ${ }^{4}$ no estado, escrito em italiano e publicado em $1925,{ }^{5}$ de autorias diversas. Considero essas publicações extremamente ricas em informações que auxiliam a recompor o quadro humano que se delineava para aqueles indivíduos que se aventuravam na empreitada migratória ocorrida em finais do século XIX e início do século XX. Foram escolhidas para estarem aqui reunidas em sintonia porque compreendo que são documentos que representam a complexidade daquele processo migratório, desde o momento de saída da Itália aos primeiros anos do processo colonizador em terras brasileiras. São obras narradoras, embora em estilos distintos, daquelas passagens e dos fluxos entre pessoas e continentes.

Estudar esse processo de um ponto de vista antropológico é um exercício delicado e limitado ao mesmo tempo, pois em mais de um século de migração observa-se o trânsito de construções sociais acerca do italiano, ora positivas, ora negativas. Como o número de informações deixadas não era grande, trabalhei com os escritos presentes nas obras acima expostas, o que é sempre um recorte interpretativo restrito, considerando-se que são registros oriundos de indivíduos inseridos em determinado contexto grupal, social e cultural, pertencentes, em sua totalidade, ao universo masculino, além de serem também traduções. A opção por trabalhar somente com essas obras no presente artigo se deve ao fato de que muitas das reconstruções locais contemporâneas acerca do "tempo dos antigos" ${ }^{\prime 6}$ sofreram a influência dos escritos de Pozzobon e de Lorenzoni, especialmente por meio das suas leituras e releituras efetuadas por agentes interétnicos, ou seja, por aqueles indivíduos que trabalham, contemporaneamente, em prol da valorização e da visibilidade da italinidade.

Esses agentes, sejam eles radialistas, padres, professores, intelectuais, membros das associações e dos circolos, memorialistas etc., assentam-se nos relatos ali contidos, mesclando-os com as narrativas que trouxeram de seu mundo familiar e de suas trajetórias particulares de vida. A junção dessas múltiplas faces narrativas gera o que denomino de processo de construção das memórias, que é sempre e ao mesmo tempo coletivo e individual. Individual, porque quem refaz as memórias com sentido é o indivíduo; coletivo porque é o grupo que lhe dá legitimidade e partilha de significação. Assim, a memória grupal é experienciada com sentido pelo descendente, que a atualiza conforme sua própria trajetória de vida, sua classe social, seu gênero etc. Nesse processo, mantém-se o que é compartilhado no presente como elemento valorativo e legítimo de ser acionado enquanto constituidor de italianidade. Para além disso, como ressalta Halbwachs (1990), somente permanece nas memórias o que é reativado constantemente como portador 
de significação e valoracão coletiva. ${ }^{7}$ Enfim, trata-se de uma leitura do passado elaborada a partir da ótica do presente. O passado - interpretado, apropriado - ressemantiza-se, e o que importa dele é o que se torna significativamente viável no presente.

Considero que os atuais descendentes de italianos souberam negociar, no mercado de bens simbólicos locais, uma imagem positiva de si mesmos mediante alguns mecanismos particulares: utilizaram sua ascensão econômica como fato promovedor da categorização do imigrante italiano como empreendedor, trabalhador e civilizador. Alguns de seus valores ideais também se tornaram ideários genéricos, tais como a religiosidade e a valorização da família como instituição primordial e mantenedora de uma determinada estrutura moral. Além disso, para as gerações atuais, as sagas migrantistas transformaram-se em exemplo a ser seguido, guiando ações. É pelo olhar atual sobre o passado que o mito de origem familiar e grupal é traçado. Essas sagas, em sua maioria, são leituras ideais sobre os pioneiros, e a sua riqueza reside justamente aí. Em termos identitários, é relevante que os elementos positivos sejam constantemente atualizados, e se eles não existirem, que sejam agregados pela força coletiva das reconstruções sobre o passado.

Dessa forma, muitos pais contam a seus filhos e netos os feitos dos antigos, sua determinação para vencer os obstáculos naturais e psicológicos, a força contra as adversidades, o modo de vida simples, a capacidade de poupança e gerenciamento familiar, a fé etc. Por meio desse processo de partilha geracional de uma memória grupal e pela invocação de uma origem diferenciada no seio da sociedade brasileira, redefinem-se constantemente. Por isso, considero melhor a referência a italianidades, construídas nos diferentes encontros dos migrantes com as localidades nas quais se assentaram. Atualmente, para além de uma identidade genérica de italianos na região central do estado, há a preocupação com o desvendar das identidades mais regionalizadas, como trentinos, vicentinos, lombardos, friulanos, vênetos etc. Considero tal dinâmica uma característica da multivocalidade desse tipo de reconstrução que, como já foi colocado, é um processo coletivo e individual e em concordância com os processos identitários contemporâneos.

A construção de uma identidade positiva foi um processo que se consolidou nas últimas décadas do século passado. Isto porque, durante o período da II Guerra Mundial (1939-1945), os italianos, em nível nacional e local, passaram por momentos difíceis, visto o Brasil ter se agrupado em 1942 aos Aliados, lutando contra o Eixo formado por Alemanha, Japão e Itália. Durante esse período, os imigrantes destes países de origem e seus descendentes foram tidos como "perigos nacionais", havendo forte repressão e perseguições, o que promoveu uma auto-imagem depreciativa da italia- 
nidade que perpassou por gerações. Naquele contexto de caldeamento (cf. Seyferth 1997:22), nacionalizar foi uma meta conduzida, em nível local, de forma bastante repressiva (vide Zanini 2005, 2006) e na qual, conforme ressalta Seyferth (1997:22), a incorporação dos desnacionalizados implicava uma "mudança de mentalidades e dos significados simbólicos atrelados a nacionalismos estranhos".

Quando iniciei minha pesquisa entre descendentes de imigrantes italianos, em 1997, procurei investigar o crescimento de um movimento étnico de italianos na cidade de Santa Maria. Contudo, ao entrar em contato com as construções elaboradas acerca da italianidade, surprendi-me com o processo presenciado: eu era espectadora da construção das memórias, muitas apagadas pelo tempo, por processos migratórios consecutivos, pelo período repressivo do Estado Novo ou mesmo pelas novas condições sociais e econômicas dos descendentes. ${ }^{8}$ Para compreender as narrativas, aventurei-me no terreno da historiografia local. Foi então que pude observar que, partindo de uma matriz discursiva comum, os descendentes atuais refaziam as sagas migrantistas. Nessas reconstruções, identifiquei alguns momentos marcantes presentes na trajetória constitutiva da italianidade: a travessia, o processo colonizador, a repressão do Estado Novo e os últimos anos, quando muitos começaram a redimensionar sua noção de pertencimento étnico. ${ }^{9}$ Mas, afinal, que passado era aquele?

\section{0 passado}

Quem eram aqueles imigrantes, quais construções identitárias possuíam sobre si mesmos, dos outros imigrantes ou dos brasileiros? Como se autoreferenciavam naquele processo de ruptura? Estas são questões respondidas de forma limitada, considero, pela literatura histórica e antropológica sobre os imigrantes. Há em comum nas diversas interpretações o fato de que aquelas populações desejavam uma melhoria das suas condições de vida, seja do ponto de vista político, religioso, moral ou do econômico. De ex-proprietários e despossuídos a massa migratória se compôs. Contudo, creio ser oportuno observar, acerca dos relatos deixados e que serão aqui analisados, que estes foram obra de indivíduos inseridos em determinada condição social e espacial. Eles não representam, com certeza, uma universalidade no que diz respeito àquelas populações. Devem ser interpretados segundo uma determinada situação histórica que possibilitou o registro daquelas impressões, ou seja, foram escritos, em sua totalidade, por homens não só alfabetizados, mas possuidores de certa instrução. 
Além disso, sobre os escritos de Lorenzoni e Pozzobon, é importante acrescentar que eles se inserem em um quadro ocidental de individualismo crescente. O ponto de vista central é o do sujeito que experimenta situações e delas extrai impressões, conceitos, refazendo a si mesmo em suas indagações, seus ressentimentos e pareceres. Enfim, ele se transforma em um formador de opinião - e isto vale para todos os textos aqui analisados. São homens vivenciando suas contradições culturais, históricas e existenciais. São vozes particularizadas num processo que foi, de certa forma, massivo, opressivo e sacrificado. A escrita, como instrumento de expressão, talvez lhes tenha permitido sobreviver melhor diante das adversidades. As tensões entre as demandas exteriores e os desejos íntimos são mais perceptíveis na narrativa de Pozzobon, porém em Lorenzoni também se observa a tentativa constante de redimensionar sua experiência migratória e as transformações que esta promoveria sobre ele (ou sobre os migrantes).

Julio Lorenzoni tinha 14 anos quando sua família decidiu migrar. Seu pai era marceneiro, proprietário de uma pequena quantidade de dois hectares de terra cultivável e de uma casa modesta, como ele mesmo narra. Estas pequenas posses não lhe permitiam um bom nível de vida na Itália daquele período. Segundo Marcon (1975:10), que apresenta o livro com as memórias do autor, Lorenzoni teria freqüentado, na Itália, a escola primária e os primeiros anos ginasiais, o que era, naquele contexto migratório, um nível de instrução incomum. Suas narrativas acerca da localidade natal, próxima a Maróstica, bem ao norte da província de Vicenza, retratam os vizinhos como pessoas pobres que vislumbraram na imigração uma alternativa de melhoria de vida.

Pozzobon, já com mais idade ao migrar, 22 anos, possuía um letramento maior, o que transparece em suas narrativas que possuem um tom marcadamente intimista. As memórias publicadas por seu neto, denominadas Uma odisséia na América, são entrecortadas por temas, intitulados Soldado do rei; Adeus às armas; Coração aflito; Com Francesca, no altar; Arriverdérci; A travessia; Siamo arrivati, entre outros. As datas vão de 1884 a 1928, no livro publicado. ${ }^{10}$ Sua família era proprietária de poucos bens, o que teria sido "torrado", segundo ele, por preços irrisórios (1997:40) quando de sua partida da Itália.

De acordo com Machado (1999:15) os imigrantes italianos que se tornariam proprietários em terras brasileiras devem ser analisados como parte integrante de um processo nacional de transição do trabalho escravo ao trabalho livre, assim como das preocupações modernizadoras e europeizantes da elite nacional. Acresceria a isto a política do embranquecimento, na qual o imigrante europeu se inseriu idealmente. ${ }^{11}$ Para Colbari (1997:54), as 
principais contribuições do imigrante italiano na constituição dos alicerces culturais e morais da sociedade brasileira seriam o familismo e a ética do trabalho, os quais se transformariam nos grandes sinais diacríticos constituintes da italianidade. Conforme ressaltado por Seyferth (1990:87), o trabalho era um demarcador de etnicidade, não somente em relação aos italianos, mas a outros grupos étnicos também. Além disso, a migração já era uma prática sazonal entre aquelas populações européias. De acordo com Alvim (2000:386), entre 1841 e 1940, 7 milhões e meio de italianos teriam migrado, sendo de vênetos a maior parte dos que rumaram para o Brasil.

As grandes migrações daquele período devem ser interpretadas, sem sombra de dúvida, considerando-se o desenvolvimento do capitalismo em nível global e o das forças de atração e repulsão de contingentes humanos. No entanto, penso que a decisão de migrar precisa ser analisada de um ponto de vista grupal, uma vez que esta foi uma migração familiar. Contudo, observando-se a autoridade paterna imperante naquelas famílias, a decisão final cabia idealmente ao homem, pai de família. Há que se considerar elementos que permitiram e favoreceram a migração de alguns e não de outros. Dessa forma, explicar o processo migratório somente a partir do enfoque econômico parece-me incompleto, uma vez que nem todos os contingentes populacionais italianos nas mesmas condições precárias de vida optaram pela migração. Percebo, nas populações migrantes, a força dos agentes migratórios e de suas propagandas, conforme está presente nos relatos de Lorenzoni, e também o fato de que migrações eram já culturalmente estratégias de sobrevivência daqueles grupos. No caso de Lorenzoni, o grande agente promotor foi um padre que, por meio de sua autoridade religiosa, muito influenciou aquelas populações com relatos extremamente positivos sobre a América.

Embora o governo brasileiro priorizasse migrantes camponeses, em todas as levas vinham também indivíduos que possuíam algum conhecimento de profissões mais especializadas. Foram estes que, em muitas situações, iniciaram o processo industrial nas cidades sulistas. Segundo Fae (1975:33), os imigrantes eram alimentados pela mística do progresso e esta "encarnava" nos braços livres dos colonos-proprietários, possibilitando ao fenômeno migratório aparecer como alavanca impulsionadora da região Sul para o "futuro".

A migração local para a colônia de Silveira Martins teria se dado, conforme Ancarani (s.d.), em levas a partir de 1877. Em seu relato, presente na Revista do Centenário de Santa Maria (1914) o autor faz referência a cada uma delas especificamente, observando também os fatos que acompanharam tal migração e um pouco dos destinos daqueles homens. A maior parte dos 
migrantes era do norte da Itália: vênetos, mantovanos, feltrinos e tiroleses que, com suas famílias, aventuravam-se na América. ${ }^{12}$ Os detalhes da chegada, da travessia e das primeiras impressões estão relatados nos escritos de Lorenzoni e Pozzobon. Para este último, foi num dia quente e ensolarado de dezembro de 1885, depois de 40 dias de navegação marítima, que a América se revelou (1997:50). Ao chegar, começam já as comparações. Não era a Itália dos "maviosos sons, cantos e poemas" que a família Pozzobon presenciava. A terra era hospitaleira, mas não era a madrepátria. As contradições desse encontro ficaram registradas para Pozzobon: "Encontrava-me desorientado, sem dúvida, e até febril. No íntimo, entretanto, algo me segredava que havíamos ingressado num país de grande futuro, abundância e vida feliz" (1997:50).

Dentre as categorias sociais e as representações presentes nas obras que servirão de matéria-prima para esta análise, deter-me-ei nos seguintes pontos: a construção do migrante do ponto de vista da origem, da religiosidade e suas significações; o processo de enraizamento na terra hospedeira; e a colonização vista como um processo civilizador que permitiu àqueles indivíduos "fazerem-se a si mesmos", ao menos, ideologicamente.

\section{A América sonhada: propriedade, fartura e família unida}

A "febre americana" (Grosselli 1987:78) agiu de forma diferenciada sobre as populações italianas. Acerca da América criou-se todo um imaginário que se encontra bem relatado nos escritos de Lorenzoni. A nova Canaã era mais do que a expectativa de uma outra vida, tratava-se de uma luta contra a imposição de determinadas condições sociais adversas que estavam para além da pobreza. Aqueles indivíduos queriam tornar-se sujeitos de sua condição histórica e ser valorizados. A migração poderia ser um fenômeno possibilitador disto, o que alguns experimentarão, ao menos idealmente, ao se tornarem proprietários de terras e negócios. Nesse aspecto, a imigração italiana para o sul do país apresenta características diferenciadas daquela que se efetivou em São Paulo. Para estes, como trabalhadores das fazendas de café, a possibilidade de se tornarem proprietários era menor. Muitos deles rumaram para os centros urbanos, proletarizando-se.

Pozzobon relata que, ao embarcarem, "quantas mulheres com os cabelos desgrenhados increpam os maridos que quiseram dar aquele triste passo". Contudo, acrescenta ele, "a culpa disso é de terem ouvido falar que na América se trabalha pouco e se vestem roupas de seda" (1997:64), ou seja, a América assegurava a possibilidade de reverter a condição social na qual 
viviam: a de seres despossuídos e sem oportunidades, numa Itália em que comiam mal, vestiam-se mal e não possuíam prestígio algum.

Tornar-se signore, isto é, proprietário, era algo muito importante para aqueles primeiros migrantes que se aventuraram rumo ao desconhecido. Julio Lorenzoni observa que o desejo era tamanho que ninguém mais queria lavrar a terra italiana, reservando-se a fazê-lo quando chegassem ao Novo Mundo, sonhando com riquezas, felicidades e bem-estar (1975:17). Era a promessa de ascensão social que na Itália se tornara, para muitos, uma impossibilidade. Mesmo sendo proprietários de terras na Itália, aqueles camponeses viviam num regime de privações, pois as colheitas nem sempre eram boas e os impostos, um pesado encargo. Aqui, no Brasil, faziam poupança para conseguir melhorar suas propriedades, adquirir animais e independência, características estas constantemente enaltecidas, atitudes por meio das quais alguns conseguiriam ascender socialmente. Segundo Lorenzoni, depois da semeadura, durante o inverno, o colono dedicava-se a construir chiqueiros, estábulos, galinheiro e a plantar uma horta. Após alguns anos de trabalho nas propriedades, diz o autor, não havia muitos contos de réis, "mas vivia-se muito bem e nunca ouvi um colono queixar-se no Brasil" (1975:102). Afinal, eram proprietários e livres.

Todavia, a partida para a América, para alguns, era também uma passagem ritual para uma nova condição social, na qual a família como um todo teria que lutar pela sobrevivência. Para aqueles que seguiram com a parentela extensa, o desconforto talvez tenha sido menor. Para Pozzobon, a emigração foi um processo complexo em relação a diversos pontos de vista: tratava-se de uma decisão paterna à qual teve que obedecer e, no decurso da travessia, ele mudaria também seu estado civil, de solteiro para casado. Diz ele que a "idéia de constituir família em terra estrangeira, completamente desconhecida até em meus livros escolares, num país onde nada e ninguém me falava ao coração" (1997:38) causava-lhe terror. E, assim, nesse quadro conflituoso, muitos migraram; como ele, sob a autoridade da decisão paterna ou familiar.

\section{Religiosidade}

A religiosidade dos italianos era algo muito particular, especialmente para aquela população camponesa migrante, analfabeta, em sua grande maioria. Como já foi ressaltado por outros estudiosos da colonização italiana no estado, não era o sentimento de pátria que os unia, mas sim a religião católica (De Boni 1980). Era ela que ordenava seu mundo e lhes permitia 
encontrar significado na experiência pela qual estavam passando, apesar das dificuldades encontradas. ${ }^{13}$ Segundo Borges Pereira (1974:120), que estudou um processo migratório italiano posterior, a instituição religiosa seria uma faixa de segurança para os colonos italianos que, ainda sem as balizas de referência para pautarem seus esquemas de pensamento e de ação, necessitariam dela para se apoiarem enquanto passavam de sua cultura de origem para uma nova realidade. Segundo Santin e Isaia (1990:18), para o imigrante italiano, a prática religiosa nada mais seria do que a confirmação de seu trabalho, de suas aspirações e de sua vida, dependentes do cultivo da terra. Penso que todas as visões acima apresentadas estejam corretas. Seja do ponto de vista emocional, psicológico ou econômico, a religião foi vital no processo de enraizamento daqueles migrantes em terras brasileiras. Diria, parafraseando Durkheim (1996), que a religião permitiu a continuidade de certa ordem de mundo, de classificações, representações e hierarquias em que a Igreja, como instituição, desempenhou um papel fundamental, aliás, indissociável da própria italianidade. ${ }^{14}$

Ao decidirem partir da Itália para o Brasil, aqueles indivíduos procuravam realizar seus rituais religiosos, uma vez que não sabiam, conforme relata Pozzobon (1997), ${ }^{15}$ a religião que era praticada na nova terra. Eram aconselhados a trazer uma garrafinha de água benta, e as crianças eram crismadas antes da partida. Igualmente, na manhã que precedia à despedida de suas localidades, uma missa era realizada a fim de que fizessem uma boa viagem. Lorenzoni assegura que, durante os primeiros anos de colonização, 1878 e 1879, a única religião que conservaram os colonos era a do coração, pois não havia igrejas ou padres. Ele sentia falta de rituais religiosos que mantivessem "vivo e ardente aquele sentimento religioso" (1975:77) que haviam trazido da Itália. Conforme o autor, a educação religiosa se dava em casa, pelas mães, que procuravam educar seus filhos na religiosidade católica. Missa só havia de três em três meses. O sentimento daqueles migrantes era o de que, sem religião, afastavam-de da civilização: "O nosso colono não podia conformar-se com esse estado de coisas: ter que morrer sem ter um padre perto que lhe desse os confortos da religião, a extremaunção, etc." (Lorenzoni 1975:77).

Em 1880, contudo, chegou o primeiro sacerdote a Silveira Martins, e os colonos, de acordo com Lorenzoni, trabalharam todos na construção da igreja. Após a chegada dos padres, foram esquecidos "os dois longos anos passados no meio do mato, à semelhança de animais selvagens" (Lorenzoni 1975:78). Segundo Santin (1986:13), a capela, o campanário e os sinos constituíram a essência de toda a vida e de todo o universo do imigrante italiano em sua nova pátria. ${ }^{16} \mathrm{~A}$ força desses elementos era aquela do mundo 
de origem e tê-los aqui, na terra estrangeira, representava a preservação de uma determinada cosmologia.

Tamanha era a importância da vida religiosa para aqueles colonizadores que o Álbum Comemorativo do Cinqüentenário possui um capítulo intitulado "A vida espiritual nas colônias italianas no Estado", escrito por Giuseppe Barea e no qual é apresentada a trajetória espiritual de cada localidade de imigração italiana no Rio Grande do Sul. Aliás, boa parte do Álbum refere-se às construções religiosas dos imigrantes: igrejas, capelas, escolas, seminários. Para Bombassaro, quem conhece a "psicologia" do imigrante italiano reconhece o fervor de seu culto: "A religião foi sempre a grande força que guiou seu espírito nas várias tristezas, constituindo fator formador benemérito da vida social e econômica deste Estado e missionário do progresso desta sua nova Pátria de adoção" (s.d.:333).

A felicidade pelo encontro com um padre, quando os emigrados rumavam para Silveira Martins, foi narrada por Lorenzoni em suas memórias. Da mesma forma, a primeira missa rezada "no bosque" pelo padre Marcelino Bittencourt, na época vigário de Santa Maria, é contada com grande entusiasmo. O relato de Lorenzoni traz até nós a igreja improvisada com lençóis, colchas, galhos de árvores com grandes folhas verdes e flores silvestres (1975:55) e a alegria, que havia sido muita, havendo inclusive batizados e casamentos. O padre, como elemento de autoridade, possuía um poder muito forte na comunidade, o que não quer dizer que sobre ele e sua conduta não pudessem ser feitas críticas ou represálias. Na história da Colônia Silveira Martins, a maçonaria desempenhou um papel muito forte, sendo até os dias atuais uma marca simbólica da localidade. ${ }^{17}$ Seria o sacerdote também que, quando italiano, lembraria constantemente àqueles homens, àquelas mulheres e crianças as suas origens. ${ }^{18}$

A leitura que os colonizadores italianos faziam dos hábitos religiosos dos brasileiros também é interessante. Embora todos fossem católicos, a forma de conduzirem sua fé era distinta, sendo os brasileiros por eles considerados pouco rígidos em sua vivência religiosa. Em sua primeira viagem de volta à Itália, Pozzobon narra que, em uma procissão de Cristo Ressuscitado, assistida em Santos - SP,

Quatro associações abrem as cerimônias, à testa suas bandeiras, todos os membros uniformizados. Segue-se a imagem de Cristo, depois a Virgem e, em seguida, o pálio sob o qual o monsenhor vigário carrega, em lugar do Santíssimo Sacramento, um pequeno crucifixo de madeira. Nunca vi isso em minha vida! São costumes locais. A procissão - deve-se dizer confusão, antes de qualquer outra coisa - excetuadas as confrarias, decorre muito desordenadamente, todos andam sem direção determinada (1997:87-8). 
Da mesma forma, observa ele que há vinte anos atrás, quando os emigrados haviam saído da Itália, todos pregavam no navio, as mães ensinavam seus filhos a orar e não se falavam tantas blasfêmias como em 1905. Segundo Pozzobon, esses novos hábitos seriam um dos frutos nefastos que se estavam colhendo nas repúblicas sul-americanas, "os quais impelem quais velas enfunadas o ateísmo sem fronteiras" (1997:91). Em 1905, seriam muitas blasfêmias e nenhuma oração. No entanto, segundo Santin, a blasfêmia era uma manifestação particular da religiosidade do migrante italiano (1986:17).

Compreendo a imigração italiana para o Brasil através de um amplo espectro, no qual se mesclam forças econômicas, sociais e culturais. Concordo com Alvim (1986) e Grosseli (1987) quando argumentam que a vinda daquelas famílias para o Brasil foi uma forma de sobrevivência cultural também. Penso que a Igreja Católica e seus valores tenham migrado junto com tais populações. Ao ler algumas citações presentes no Álbum, observase o seguinte:

De fato, as famílias italianas que vieram povoar o estado eram pobres, pouco instruídas, mas de ótimos costumes, profundamente religiosas; camponeses vindos dos montes do Vêneto ou das planícies da Lombardia, quando ainda a corrupção e a descrença não tinham saído dos limites das cidades para se alastrarem nas aldeias e lugarejos do campo. Aqui, vivendo em colônia e nos pequenos centros, conservaram inalteradas as tradições de origem, e foi com certa maravilha e surpresa que os novos emigrados chegados no pós-guerra constataram belos hábitos familiares que, na Itália, contudo, haviam caído em desuso (Benvegnu s.d.:145).

Prossegue ele, enaltecendo o ambiente "moralmente sadio" em que viviam aqui, em solo brasileiro, aquelas famílias.

No texto elaborado por Gobatto para o Álbum, denominado de "Il colono italiano ed il suo contributo nello sviluppo dell'industria riograndense", o imigrante italiano é classificado como muito trabalhador, humilde e religioso, apresentando o processo colonizador como uma luta entre o homem e a natureza hostil. A religiosidade, naquele contexto, talvez tenha se tornado maior do que o era na própria Itália, uma vez que por meio dela é que extraíam de si mesmos forças para lidar com as adversidades cotidianas. Pelas crenças e pelos ritos religiosos lembravam-se de quem eram, de onde haviam partido e quais os seus objetivos. Nas colônias, muitos permaneceriam camponeses, favorecendo a vivência de uma determinada religiosidade mesclada à terra e aos ciclos naturais. Contudo, aqueles que rumaram para as zonas urba- 
nas desempenhando outras atividades também mantiveram a religiosidade como importante sinal adscritivo, conforme verificado em minha pesquisa etnográfica realizada de 1997 a 2001.

\section{As formas de sociabilidade}

A sociabilidade daqueles colonos era limitada às festas religiosas, à missa dominical, quando se reuniam na igreja e, em seguida, na bodega, na qual compravam artigos que não produziam para o sustento familiar. Ali também ficavam a par dos acontecimentos mais distantes e, algumas vezes, recebiam notícias da "patria lontana". Julio Lorenzoni narra que, em 1879, já possuindo ele seu cavalo, que era um símbolo de status, rumava para a sede de Silveira Martins. Lá, aos domingos, encontravam-se os colonos, e as casas comerciais enchiam-se de gente. Nelas, bebiam e comiam. Depois, iam fechar seus negócios e fazer compras. A maioria logo voltava para casa, outros, porém, ficavam para jogar a mora, jogar bochas, de modo que alguns retornavam a casa "bem alegres" (1975:73). Esse era um universo primordialmente masculino, pois as mulheres, depois da missa - quando iam tinham que retornar a casa e cuidar da prole, dos animais e dos demais serviços domésticos.

Segundo Bombassaro, em Silveira Martins, aos domingos, quando os imigrantes se reuniam, o que se ouvia era o dialeto vêneto, dando a impressão de se estar nos "lugarejos do Vêneto" (s.d.:333). Afirma o autor também que os divertimentos do colono vêneto eram os jogos de bochas, o tressete, o canto e "il vino" (s.d.:333). Para as mulheres, a sociabilidade resumia-se praticamente aos acontecimentos religiosos. A escola era ainda um universo majoritariamente masculino. O canto também era uma forma de expressão cultural. Lorenzoni narra que, no caminho inicial que fizeram até a Colônia, do "Jacuí à boca da picada", as jovens camponesas, de braços dados umas com as outras, entoavam cantos do folclore italiano, "doces e melodiosos, que ecoaram por aquele imenso descampado" (1975:44). Os "filhos do país", os carreteiros, teriam ficado estupefados com aquelas harmoniosas vozes, afirma ele.

Para melhor conviverem entre os iguais, criaram as Sociedades de Mútuo Socorro. Em 1925, de acordo com as informações contidas no Álbum, haveria 64 associações italianas no estado, 26 das quais possuidoras de sede própria (s.d.:364). Essas sociedades tinham por objetivo prestar auxílio aos imigrantes, bem como manter vivos determinados vínculos com a madrepátria. A Societá Italiana di Mutuo Soccorso, de Santa Maria, fundada em 1896, tinha como objetivos: união e "fraternização" dos italia- 
nos, assistência em casos de doença ou de impossibilidade de trabalhar e também possibilitar o melhoramento material e a elevação moral dos sócios e da Colônia (s.d. 1925:391). Em São Marcos (Arroio Grande), foi criada a Sociedade Duca degli Abruzzi, em 20 de setembro de 1896 e, em Silveira Martins, a Umberto I.

\section{O modo de vida: privações, poupança, simplicidade e ascensão social}

O colono é apresentado no Álbum como adepto de uma vida simples: “Trabalhadores incansáveis, com toda a família — incluindo a esposa - o colono pouco tempo perde com a construção da casa e menos ainda com o seu embelezamento" (Gobatto s.d.:236).

Conforme Lorenzoni, os colonos, ao receberem seus lotes, começavam a limpeza do terreno e tratavam de armar uma cabana de pau-a-pique, "coberta de folhas de palmeira, que havia de servir de primeiro abrigo para sua família" (1975:64). Para dormir, faziam camas com quatro paus fincados no chão batido, a meio metro de altura, com tábuas atravessadas por cima, cobertas com ervas secas. Este foi o modo de vida dos primeiros colonizadores, "feito de privações", como bem ressalta o autor. Como alimento, naqueles primeiros tempos, diz ele que o café da manhã era composto de mate com algumas bolachas secas e duras, e o almoço, de sopa de arroz com feijão, o que era repetido no jantar. Observa-se que a simbologia do imigrante italiano como ostentador de uma mesa farta, como se verá no ano de 1925, quando das comemorações do Cinquentenário, não era algo que estivesse na simbologia do pioneiro. A sua imagem é a do homem sob privação. Viviam com poucos recursos na Itália e aqui também na condição de imigrantes recém-chegados. Será por meio do processo colonizador que a comida farta se transformará num símbolo da ítalo-brasilianidade.

A primeira casa, construída após alguns meses de trabalho, segundo Lorenzoni, era de madeira, com cozinha ao lado, na qual se instalava o focolare (fogareiro artesanal, feito de forma rudimentar), "sua pia para lavar a louça, também de madeira, e uma prateleira com grandes ganchos para pendurar o balde d'água, as panelas e outros utensílios" (1975:69). Enfim, aos poucos, reproduziam em termos espaciais as categorias culturais européias. O processo de enraizamento no Brasil será uma mescla da cultura de origem com as novas formas ecológicas, geográficas e sociais encontradas. Battistel (1981:38), ao se referir aos imigrantes italianos de um modo geral, salienta que as capelas eram muito mais bonitas do que suas próprias casas. Isto 
acontecia porque investiam seus recursos na sua construção e na das igrejas, possibilitando dessa forma estabelecer estruturas de significado em torno de tais instituições e do poder simbólico delas emanado. Enfim, quanto mais belas as edificações religiosas, melhor seria idealmente aquele povo, mais abençoada e melhor situada economicamente estaria aquela população.

Para Belém (1989), em sua obra História do município de Santa Maria, publicada em 1933, as vestes dos italianos seriam "uma curiosa exposição de todas as modas que passaram", sendo que a policronia dos vestidos e dos lenços embaralhava a visão do observador: " [...] o encarnado, o verde, o amarelo berram para que lhes prestem atenção e seguem satisfeitos para a casa do senhor" (1989:168).

\section{A colonização interpretada como processo civilizador}

Pozzobon relata que, em 1906, 21 anos depois de ter chegado ao Brasil, o imigrante europeu que aqui chegasse maldiria a sorte e haveria de se horrorizar diante de tanta solidão. Diz ele:

Imaginem agora os leitores deste começo de século XX, o turbilhão de idéias que em 1885 se apossou de meu espírito, ao ver e sentir a imensidão desta paisagem rude... É neste ambiente que hoje trabalham e vivem felizes milhares de italianos e seus descendentes brasileiros (1997:53).

Em vários momentos do Álbum e também dos escritos de Lorenzoni e Pozzobon, o processo migratório é apresentado como uma empreitada civilizadora. No artigo escrito por Truda para o Álbum há, inclusive, em várias passagens, apologias ao branqueamento ("processo di chiarificazione") provocado pela imigração dos italianos. Os escravos, segundo o autor, eram considerados uma "perturbação econômica": "e este motivo bastava para excluí-lo, sem ser necessário invocar outras razões de ordem étnica ou social" (s.d.:246). O negro era tido como raça inferior. Os italianos são apresentados por Truda como uma população fisicamente saudável e forte, não somente quanto ao aspecto físico, mas moral também (s.d:249). Ao finalizar o artigo, ele ressalta, referindo-se à industrialização promovida pelos italianos no estado:

Este fato revela no trabalhador italiano não somente uma rara tenacidade, uma insuperável capacidade de trabalho, uma energia indomável mas, ao mesmo tempo, a febre de melhorar e aquele grande espírito criativo que o faz elemento incontestável de progresso para os países que o acolhem (s.d.: 254). 
Cichero (s.d.:312) nos relata que o colono italiano possuía algo mais que braços vigorosos, adaptando-se a uma vida de privações que outras "raças" refugariam. O italiano seria dono de um espírito atávico, civilizador por natureza e que, segundo o autor, teria deixado suas marcas nos monumentos por ele construídos no velho mundo (s.d:312). Assim, diz ele, aqueles imigrantes não conheciam obstáculos quando se tratava de transformar um país selvagem em um centro moderno (s.d.:312).

Para Bombassaro, também presente no Álbum, os colonos italianos não conheciam a vida nas matas, mas com força de vontade, sacrifício e trabalho venceram as dificuldades e transformaram aquelas áreas em centros agrícolas. Afirma também que, quando o governo determinou o pagamento das terras, todos os colonos de Silveira Martins, em 90 dias, teriam liquidado inteiramente os seus débitos; em contrapartida, colonos de outros lugares teriam levado até trinta anos para fazer o mesmo (s.d.:332). O comitê de Arroio Grande relata no Álbum que:

Com o desmatamento da selva virgem e o trabalho constante frente aos obstáculos, as inundações foram evitadas. Com a sistematização das terras liberadas de tanto flagelo, melhoraram aos poucos as condições de higiene, morais e econômicas dos colonos italianos que, se hoje possuem um relativo bem-estar, sabem o quanto de privações, de dificuldades, de suor, de sangue e de sofrimentos foi preciso para conquistar este aparente bem-estar (s.d.:335).

Em algumas passagens do Álbum há a tentativa de desfazer a idéia de que a imigração italiana foi somente uma imigração braçal. Segundo os relatores, havia trabalhadores do "pensiero", que deixaram suas marcas na arte e na ciência (s.d.:441). Quanto à região de Santa Maria, é exposto que quase todas as famílias que formavam em 1925 "a próspera colônia italiana" local seriam provenientes de Silveira Martins, já que começaram a procurar novas terras e condições de vida a partir de 1885.

Crocetta, também autor do Álbum, num tom evolucionista, citando inclusive Darwin, afirma que os indivíduos migrantes eram sempre os mais fortes e também aqueles capazes de gerar proles sadias e firmes moralmente (s.d.:457-8). A interpretação da migração como um processo civilizador está também presente em narrativas de descendentes atuais, que assim vêem os feitos de seus antepassados, embora não necessariamente de forma evolucionista - fato este encontrado na literatura histórica e antropológica, não somente entre descendentes de italianos, mas de vários grupos migrantes. Antes, as matas e o espaço vazio; depois, a civilização, o progresso e a cultura. Vittorio Buccelli, em sua obra Un viaggio a Rio Grande del Sul, publicada 
em Milão no ano de 1906, ao entrar na localidade de Arroio Grande, narrou: "Quando chegamos no centro da pequena vila em frente à Igreja, tivemos a ilusão de estarmos vendo um pedaço da Itália na hospitaleira terra do Rio Grande do Sul" (1906:345).

A questão da invocação do pioneirismo é uma constante entre grupos migrantes no sul do país, para os quais o processo colonizador se reveste de uma aura civilizatória, civilização esta calcada numa domesticação do espaço e dos processos produtivos em consonância com os modelos trazidos da Europa. A noção de espaço vazio também é uma constante nessas narrativas. Os habitantes locais são invisibilizados, mesmo que vizinhando com os colonizadores, os quais se sentem legitimados para assumir seus postos de donos das terras.

\section{A ítalo-brasilianidade}

Pozzobon relata que ao saírem de Santos, após sua chegada ao Brasil em 1885, puderam dar adeus àquela tão antipática cidade, na qual a "negrada" os chamava de carcamanos, ${ }^{19}$ gringos, ladrões etc., situação que os recémchegados achavam humilhante. Esses elementos devem ser considerados num contexto em que os imigrantes eram observados como agentes de transformação e de competitividade em nível nacional. Aliás, o termo "negro" era usado pelos imigrantes italianos como forma genérica para determinar os brasileiros. Não residia aí classificação biológica somente; ela era prioritariamente cultural. A brasilidade será incorporada em termos identitários, aos poucos e de forma diversa, conforme os contextos históricos exigirem.

Há de se observar que, ao saírem aqueles migrantes da Itália, esta havia se unificado há pouco e, de fato, não possuía enquanto nação um sentimento comum de pertencimento. Lorenzoni narra que, no vapor em que veio para o Brasil em 1877, o que se ouvia era uma mistura de vários dialetos, muitos dos quais ele nada compreendia. Enfim, eram pessoas culturalmente diversas que, na situação de partida, tornaram-se genericamente italianos. Na Itália havia rivalidades entre as localidades, e a aparente noção de homogeneização cultural se daria no Brasil, quando de emigrados italianos passariam a imigrantes italianos e, depois, a colonos proprietários. ${ }^{20}$

O encontro com a diversidade brasileira também chamava a atenção no momento de encontro com os nacionais. Lorenzoni narra que, ao descer no porto de Rio Grande, observou a presença de portugueses, que ele distingue de brasileiros e de escravos, negros e mulatos (1975:36). Ao chegar a Porto Alegre, novamente os negros e os mulatos se fizeram notar por ele, que teceu 
comentários sobre a forma como as mulheres negras eram tratadas. Na Itália, segundo Lorenzoni, que em mais de um momento se refere aos negros, não havia população desta cor, o que favorecia o estranhamento inicial.

"Ítalo-brasileiros" - este é o termo que se apresenta nas páginas do Álbum, em 1925. Para aqueles imigrantes que estavam em processo de enraizamento em solo brasileiro, definir-se não era algo tão fácil, pois fora aqui que haviam se tornado proprietários, sonho maior de todos. Contudo, muitas relações afetivas e de parentesco haviam permanecido na Itália. Esta também, como madrepátria, desempenhava um papel importante em suas auto-atribuições. Isto pode ser observado através de fatos, como o grande número de sociedades italianas e a construção em 1927, em Arroio Grande, distrito de Santa Maria, do monumento aos italianos mortos na Líbia.

Pozzobon narra que, ao chegarem a Porto Alegre em dezembro de 1885, surpreenderam-se com a fartura da terra brasileira: carne bovina, suína, ovina, aves, peixes, verduras e frutas. O "nonno" Pozzobon, de 77 anos de idade, teria comentado: "Esperava encontrar aqui, ao chegar, o leão baio, tigres e macacos. Agora como uma bela melancia" (1997:50-51).

Enfim, a terra brasileira era a terra da fartura a ser por eles colonizada e cultivada. A brasilianidade foi, de certa forma, construída atrelada à noção da terra como propriedade, da comida e da manutenção da ordem familiar. A comida, aliás, desempenhará um papel adscritivo fundamental na condição de colono italiano.

No Álbum, já era observável a produção de uma ítalo-brasilianidade. Talvez não a pretendida pelo Estado brasileiro, como se verá anos mais tarde no período do Estado Novo. Porém, de forma embrionária, em 1925, lá estava ela. Segundo Crocetta, que escreveu talvez um dos textos mais críticos do Álbum, todos aqueles emigrantes, na Itália, eram gente supérflua, mas aqui no Rio Grande do Sul estariam cumprindo seus "luminosi destini":

Em toda a vida psicológica destas populações, se há um passado de memórias para com a pátria de origem, há também um presente de trabalho e de fecundidade para com a pátria de adoção, que reforça a base da prosperidade econômica e que aumenta e robustece a governança social (s.d.:455).

E prossegue ele, em outra citação, dizendo que os italianos fizeram obras econômicas e sociais que resultaram em benefício não da italianidade, mas do progresso brasileiro (s.d.:461).

Ele critica os míopes, que diziam estar nessa construção híbrida o naufrágio da italianidade. Para ele, em seio brasileiro, no encontro com outros grupos étnicos, teria havido uma valorização da italianidade. A ita- 
lianidade, "princípio formador das consciências novas", não se perderia na assimilação, devido à sua grandeza e história. Pozzobon, ao desembarcar em Porto Alegre em 1885, também comenta a diversidade étnica encontrada: negros nas ruas e nas praças; "as mulheres com imaculados vestidos brancos, quase todas descalças" (1997:51); alemães e austríacos que falavam a língua nativa "eram fortes, loiros e de olhos azuis, e as mulheres, bastante corpulentas" (1997:51); italianos morenos e de baixa estatura, ao que ele acrescenta - "pelo dialeto que falavam, percebia-se que procediam do sul da Itália" (1997:51). Enfim, a alteridade produzia-se já no processo migratório que começara na Itália, prosseguiu nos navios e aqui se desenvolveu numa nova dinâmica, através da qual farão uso da identidade genérica de italianos. O que não quer dizer que na distribuição dos lotes, como relata Lorenzoni, não procurassem ficar perto de seus conterrâneos de localidades, falantes dos mesmos dialetos e devotos dos mesmos santos. Foi assim que se estabeleceram as linhas e suas distribuições: friulanos de um lado, vênetos de outro, mantovanos de outro...

\section{Exaltações à "raça"}

Do Lacio vem meu sangue, das serenas

Regiões das tardes diaphanas, tranquillas,

Onde é mais branco o marmore nas "villas",

E há mais uncção no coro das novenas!

Sangue latino — só, fluido, aurora

Que me ilumina o peito, e onde, sem calma,

Delira um Buonarroti e um Dante chora.

(Fornari s.d.:323) ${ }^{21}$

Na introdução do Álbum, escrita por Luigi Arduini, o caráter da imigração italiana é apresentado como "trabalho incansável, silencioso e fecundo sobre esta terra" o qual seria um dos mais gloriosos da história da emigração italiana para as Américas (s.d.:25). Nessa mesma introdução, não faltam elogios aos colonizadores, como à simplicidade dos costumes, à constância na superação de adversidades e também à presença inabalável de seu amor pela "pátria distante" (s.d.:25).

Bombassaro, ao descrever a chegada dos primeiros emigrados italianos à Colônia Silveira Martins, ressalta que, apesar de eles terem tido um triste encontro com os "poloneses" que abandonavam as terras para as quais eles estavam se dirigindo, e de esse encontro ter causado profunda consternação 
naquelas famílias, "filhos de uma raça forte e trabalhadora, os humildes colonizadores, com lágrimas nos olhos, continuaram a dolorosa viagem em meio ao mato, até que chegaram ao núcleo colonial abandonado pelos poloneses" (s.d.:329).

Enfim, aquele indivíduo emigrado, agora imigrante, seria um forte, um corajoso. No texto elaborado pelo comitê de Arroio Grande para o Álbum, foi também enfatizado que, apesar das dificuldades encontradas pelos primeiros colonos, estes não se abatiam "sofrem e trabalham com aquela tenacidade que é peculiar à nossa estirpe" (s.d.:335). E acrescenta que "a virtude da raça prevaleceu e dominou a natureza" (s.d.:335). Esta seria, talvez, a representação mais forte acerca do colonizador: aquele que domina a natureza, que civiliza, que habita o espaço vazio e o humaniza por meio da sua domesticação.

Julio Lorenzoni, ao narrar a infelicidade de imigrantes mortos no barracão em 1878, afirma que diante de tanta miséria, de tanto sofrimento e de tantas dores "assim mesmo o colono italiano não desanimava. Impávido, superava todos os obstáculos e todas as desgraças que ameaçavam até sua própria existência" (1975:53). É esta a construção que observo como um traço ideal do colonizador, traço este que tem perpassado gerações. O pioneiro colonizador, o antepassado, do ponto de vista do descendente atual, é o iniciador do mito de origem familiar, da saga migrantista. É partindo dele que as narrativas familiares se reconstroem. Poucas críticas ouvi a esses antepassados durante minha pesquisa etnográfica (de 1997 a 2001). Na maior parte das vezes, suas figuras assumem um espaço sagrado, seja por meio das memórias familiares, seja por objetos que eles tenham deixado - alguns, inclusive, garimpados por anos a fio entre a parentela extensa e expostos em salas de estar como relíquias da família. O passado familiar transforma-se, assim, em patrimônio que agrega valor aos indivíduos inseridos em mercados simbólicos mais amplos, nos quais a italianidade é avaliada positivamente.

Como antropóloga, não poderia deixar de observar que a noção de raça, em termos sociais, é vazia. As diferenças classificatórias entre seres humanos, tomando por base diferenças raciais, são altamente questionáveis. O racismo e seus mais diversos derivados são produtos históricos e, portanto, transformáveis. As concepções que aqueles indivíduos trouxeram para cá em finais do século XIX não são as mesmas de hoje, e os descendentes atuais, em grande parte, estão conscientes disso. A valorização de suas trajetórias não implica, necessariamente, a depreciação dos demais grupos étnicos nacionais, embora as fronteiras étnicas sejam delimitadas pelas diferenças entre nós e "os outros". Mesmo assim, observo que o processo de invisibi- 
lização dos diferentes demarcados pelo adscritivo de "brasileiros" ainda permanece, especialmente nas colônias.

\section{Considerações finais}

Apesar de a Colônia Silveira Martins ter sido extinta oficialmente em finais do século XIX, a denominação continuou existindo por meio da sede, que se transformou em distrito agregado à Santa Maria e, posteriormente, foi emancipada (em 1987), transformando-se no município de Silveira Martins, considerado hoje o berço da colonização italiana na região central do estado. A colonização italiana na região que hoje se denomina a "IV Colônia" é ainda pouco estudada. As próprias delimitações territoriais são, em meu entendimento, mais simbólicas do que geográficas. Sobre os aspectos históricos da colonização local, alguns descendentes têm escrito memórias, genealogias e, em 2001, foi lançada uma obra intitulada Povoadores da IV Colônia (Righi et alii 2001), que merece ser analisada pela rica documentação que apresenta.

Este artigo teve o intuito de apresentar, mesmo que de forma breve, um pouco do aspecto cultural desses imigrantes e o modo como aqui, no Brasil, transformaram a si mesmos em italianos. As identidades regionais e locais que traziam com eles eram fonte de referência entre os iguais, mas perante os brasileiros eram todos genericamente italianos, "gringos". O encontro com a diversidade nacional e o processo de enraizamento em terra estrangeira permitiu a eles redefinirem-se. Aqui, no Novo Mundo, dá-se o encontro com novas formas de ser, com uma natureza hostil que aos poucos - ao ser domesticada de acordo com valores europeus - permitirá que eles se tornem proprietários e possuidores de algum capital, fato impensável para alguns na Itália. Outros - aqueles que não se encontraram na empreitada migrantista - necessitam ser ainda estudados, pois os relatos, poucos e limitados, na maioria das vezes falam somente da parcela que se adaptou. Mas quantos não teriam se adaptado? E por quê?

As sagas migrantistas, embora possam ter um valor histórico questionável, são inestimáveis, do ponto de vista antropológico, pois alertam o pesquisador acerca das categorias que, no presente, merecem ser acionadas sobre o passado. Entre tradições inventadas ou ressignificadas (ou não), a história se refaz. Para o antropólogo, a riqueza dos escritos históricos consiste em poder neles observar, mesmo que de uma forma limitada (como foi o meu exercício neste artigo), o modo como se posicionavam, em termos sociais (espaciais e temporais também), aqueles homens e aquelas mulheres 
e crianças - observar não só a maneira como viviam mas, acima de tudo, o que permitiu historicamente que eles se reproduzissem culturalmente, considerando-se que a cultura é sempre um campo aberto, dinâmico, vivido por personagens reais que sentem, pensam, agem e procuram sobreviver, física ou psicologicamente. Esses sujeitos são negociadores que aprenderam a se referenciar conforme as interações sociais advindas de suas demandas. As ítalo-brasilianidades são negociações, seja em termos individuais ou coletivos. Embora se baseie num passado tido como fonte, trata-se de uma construção do presente sobre o passado, clivada por situações de classe, gênero, idade, entre outras.

Recebido em 30 de outubro de 2006

Aprovado em 09 de abril de 2007

Maria Catarina Chitolina Zanini é professora da Universidade Federal de Santa Maria — RS. E-mail: <cmzanini@terra.com.br>

\section{Notas}

${ }^{1}$ Utilizo a noção de região central do estado do Rio Grande do Sul para me referir à IV Colônia de Imigração Italiana, bem como à cidade de Santa Maria e vizinhanças. Não encontrei referências históricas acerca de como surgiu a denominação de IV Colônia. Por meio de relatos, soube que essa alcunha teria sido atribuída pelo padre Luisinho Sponchiado, estudioso da imigração italiana local, durante festejos do Centenário da Imigração Italiana no estado, em 1975. A denominação de Quarta Colônia ter-se-ia dado devido ao fato desta ser, em termos cronológicos de criação, a quarta, uma vez que já havia três: Conde D'Eu (Garibaldi), Dona Isabel (Bento Gonçalves) e Campo dos Bugres (Caxias). A denominação IV Colônia, contudo, na contemporaneidade, possui um valor de referência concreto e simbólico ao mesmo tempo. Os municípios que fazem parte dessa região cultural e geográfica são: Agudo, Dona Francisca, Faxinal do Soturno, Ivorá, Nova Palma, Pinhal Grande, Restinga Seca, São João do Polêsine e Silveira Martins. No entanto, para fins de análise, prefiro referir-me à região central do estado, uma vez que houve uma reimigração de muitas famílias de imigrantes italianos da Colônia Silveira Martins para Santa Maria e vizinhanças municipais, como Jaguari, São Pedro, São Sepé, Julio de Castilhos, entre outras localidades que não fazem parte da IV Colônia especificamente. 
2 Júlio Lorenzoni nasceu em Vila Raspa, Itália, em 23 de março de 1863, e faleceu em 22 de maio de 1934, em Bento Gonçalves-RS, Brasil.

${ }^{3}$ Não consegui obter a data correta de seu óbito. Nas memórias publicadas, a última narrativa que contém sua presença viva, de autoria de Zolá Franco Pozzobon, é datada de 1935.

${ }^{4}$ Nele aparecem, nas primeiras páginas, entre outras, fotos de Vittorio Emanuele III, rei da Itália, e de Benito Mussolini (denominado "capo del Governo"), de Artur Bernardes (presidente brasileiro) e de Borges de Medeiros (na época presidente do estado do Rio Grande do Sul).

${ }^{5} \mathrm{O}$ ano de 1925 é reconhecido historicamente como a data oficial de publicação do Álbum Comemorativo do Cinqüentenário da Imigração Italiana no estado do Rio Grande do Sul, contudo, tecnicamente a obra não possui dados catalográficos que me permitam oferecer informações mais precisas. Assim, quando utilizar os textos nela contidos, por orientação de especialista, adotarei a classificação s.d. (sem data). Embora se afirme que tenha sido a Livraria Globo que a publicou, ainda segundo orientações técnicas, uma vez que isto não está registrado na publicação, usarei a classificação s.l. (sem local) na referência bibliográfica acerca desta publicação.

${ }^{6}$ Processo que foi por mim pesquisado junto aos descendentes de italianos locais de 1997 a 2001. Ao retomar a pesquisa etnográfica em 2006, pude constatar o quanto estas duas memórias têm crescido em força e em número de leitores. Minha pesquisa etnográfica inicial resultou em tese de doutorado defendida em 2002, no Programa de Pós-graduação em Antropologia Social da USP, convertida em livro publicado em 2006, intitulado Italianidade no Brasil Meridional. A construção da identidade étnica na região de Santa Maria-RS (Zanini 2006).

${ }^{7}$ Para Halbwachs, "acontece com muita freqüência que nos atribuímos a nós mesmos, como se elas não tivessem sua origem em parte alguma senão em nós, idéias e reflexões, ou sentimentos e paixões, que nos foram inspirados por nosso grupo" (1990:47). Contudo, ressalta o autor, "No mais, se a memória coletiva tira sua força e sua duração do fato de ter por suporte um conjunto de homens, não obstante eles serem indivíduos que se lembram enquanto membros do grupo" (1990:51).

${ }^{8}$ Os motivos que conduziam esses indivíduos a recomporem as trajetórias familiares eram diversos, desde a montagem de processos para obtenção de dupla cidadania, até a simples curiosidade de desvendar o passado familiar.

${ }^{9}$ Compreendo os descendentes de italianos de Santa Maria como grupo étnico no sentido que lhe é atribuído por Barth (2000), ou seja, são grupos organizacionais. As identidades étnicas estabelecem-se em processos situacionais nas interações sociais e o fazem por meio da construção das fronteiras interétnicas, utilizando-se de sinais diacríticos que estabelecem as formas de auto-reconhecimento e de reconhecimento pelo outro. A identidade étnica de italianos é acionada em referência contrastiva aos demais brasileiros. É uma identidade situacional e processual, não é fixa ou definitiva, é antes um recurso interativo classificador. 
${ }^{10}$ Segundo Zolá Franco Pozzobon, Andrea Pozzobon teria escrito em italiano suas memórias já na condição de imigrante e residindo no interior de Santa Maria, RS. Segundo o autor (neto do memorialista), muitas "páginas estavam maltratadas pelo tempo e pelas traças" (1997:17) quando foram traduzidas para publicação.

${ }^{11}$ De acordo com Colbari (1997:54), a imigração italiana deve ser compreendida enquanto componente de um projeto de gestão da população, o que envolvia o adensamento, o branqueamento e a elevação civilizatória dos habitantes do país.

${ }^{12} \mathrm{Na}$ primeira leva teriam vindo, segundo Ancarani, as famílias de Prospero Pippi, Pedro Sala, Francisco Mezzomo, Borin, Dotto, Rech, entre outros. Depois de alguns meses, teriam chegado ao barracão, onde eram alojados os migrantes recémchegados, 70 famílias mantovanas. Em abril de 1878, mais 50 famílias do Tirol e, em maio do mesmo ano, outras 120 famílias (não diz a origem). Em 1881, teriam chegado mais 90 famílias e em 1885, outras 9 (1914:s.p).

${ }^{13}$ Segundo De Boni, "Unia-os, não o sentimento de pátria, pois não eram nem brasileiros, nem italianos. Chegados há pouco, sentiam-se estrangeiros no Brasil. Mas também não eram italianos emocionalmente: o país de origem, recém-unificado, de forma anticatólica, atingira as convicções religiosas dos camponeses do norte italiano. Também não se agrupavam ao redor da língua, pois cada grupo falava seu dialeto, ignorando a língua oficial da pátria que acabara de surgir" (1980:235).

${ }^{14}$ Para Durkheim, "todas as crenças religiosas conhecidas, sejam simples ou complexas, apresentam um mesmo caráter comum: supõem uma classificação das coisas, reais ou ideais que os homens concebem, em duas classes, em dois gêneros opostos, designados geralmente por dois termos distintos, que as palavras profano e sagrado traduzem bastante bem" (1996:19).

${ }^{15}$ Embora na obra Uma odisséia na América não fique esclarecido se Pozzobon seria maçom ou não, sabe-se que muitos dos membros das Sociedades de Mútuo Socorro eram também maçons.

${ }^{16}$ Segundo Santin, "Diante da imensidão das dificuldades para realizar os sonhos já acreditados, e diante da impossibilidade de um retorno, a crença em Deus e nas forças espirituais tornam-se o único refúgio encontrado. Naquelas alturas só Deus e as forças sobrenaturais poderiam, segundo eles, sustentar a coragem e a esperança nos dias melhores sonhados e acreditados" (1986:17)

${ }^{17}$ Fato analisado por Luiz Eugenio Vescio (2000) em sua tese de doutorado denominada $O$ crime do padre Sório. De acordo com o autor, muitos padres eram maçons e muitos maçons eram católicos: "O catolicismo luso-brasileiro, com suas irmandades e confrarias, possibilitava que a fé e a cultura, o religioso e o social caminhassem muito próximos, ou até mesmo de mãos dadas (2000:69).

${ }^{18}$ Segundo Barea, "Ele fala ao emigrado em sua língua, lembra-lhe aquela povoação amada que deixou além-mar. Narra-lhe acontecimentos históricos da Itália. 
Recomenda-lhe preservar as tradições da família, da Pátria, da Religião. Estimula-o a jamais esquecer os ensinamentos da virtude e da moralidade, ouvidos dos lábios do pai, da mãe, do sacerdote, do professor" (1995:14).

${ }^{19}$ Para Carelli (1985:19), o termo carcamano teria origem na expressão "calca la mano", "ordem que os comerciantes davam aos auxiliares para que arredondassem o peso das mercadorias forçando a mão sobre o prato da balança". O que significava pejorativamente "ladrão". Termo, aliás, que muitos de meus entrevistados diziam ser usado pelos nacionais para descrevê-los.

${ }^{20} \mathrm{O}$ termo "colono" foi um designativo dado pelos nacionais aos imigrantes que habitariam as colônias, diferente do que aconteceu em São Paulo, onde colono equivalia a operário agrícola. Concordo com Seyferth (1993) ao enfatizar que a qualificação de colono, no sul do país, implica, além de um pertencimento tradicional à comunidade rural, a alusão àquele que teria ascendência européia.

${ }^{21}$ Este poema, escrito por Ernani Fornari, denominado "Latinidade", encontrase nos apêndices do Álbum Comemorativo do Cinqüentenário.

\section{Referências bibliográficas}

ALVIM, Zuleika Maria Forcione. 1986. Brava gente! Os italianos em São Paulo 1870-1920. São Paulo: Brasiliense. . 2000. "O Brasil italiano (18801920)". In: B. Fausto (org.), Fazer a América. São Paulo: EDUSP. pp.383-417.

ANCARANI, Umberto. [s.d.]. "Monographia sobre a origem da ex-colonia italiana de Silveira Martins 18771914". Revista Commemorativa do Centenário da Fundação da Cidade de Santa Maria-RS 1814-1914. [s.l.].

BAREA, Giuseppe. [s.d.]. "La vita spirituale nelle colonie italiane dallo stato". In: Cinquantenario della colonizzazione italiana nel Rio Grande del Sud 1875-1925. [s.l.; s.n.]. pp.55-131. 1995. A vida espiritual nas colônias italianas do estado do Rio Grande do Sul. Porto Alegre: EST.
BARTH, Frederik. 2000. "Os grupos étnicos e suas fronteiras". In: T. Lask (org.), O guru, o iniciador e outras variações antropológicas. Rio de Janeiro: Contra Capa Livraria. pp.25-67.

BATTISTEL, Arlindo. 1981. Colônia italiana: religião e costumes. Porto Alegre: EST.

BELÉM, João. 1989. História do município de Santa Maria 1797-1933. Santa Maria: Edições UFSM.

BELTRÃO, Romeu. 1979. Cronologia histórica de Santa Maria e do extinto município de São Martinho 1787-1930. $2^{\mathrm{a}}$.ed. [s.1.].

BENVEGNÚ, Cleto. [s.d.]. "Sacerdoti italiani che precedettero l'emigrazione". In: Cinquantenario della colonizzazione italiana nel Rio Grande del Sud 1875-1925. [s.l.; s.n.]. pp.135-149. 
BOMBASSARO, P. Antonio. 1925. “Ex-Colonia Silveira Martins". In: Cinquantenario della colonizzazione italiana nel Rio Grande del Sud 1875-1925. [s.l.; s.n.]. pp.328-334.

BORGES PEREIRA, João Baptista. 1974. Italianos no mundo rural paulista. São Paulo: Pioneira/ Instituto de Estudos Brasileiros da USP. . 1987. "O imigrante italiano no mundo rural paulista". In: L. A. De Boni (org.), A presença italiana no Brasil. Porto Alegre: EST. pp. 224-250.

BUCCELLI, Vittorio. 1906. Un viaggio a Rio Grande del Sul. Milano: Officine Cromo-tipografiche.

CARELLI, Mário. 1985. Carcamanos e comendadores. Os italianos de São Paulo: da realidade à ficção (19191930). São Paulo: Ática.

CICHERO, Lorenzo. 1925. "L'emigrazione agli stati del Brasile". In: Album do Cinquantenario della colonizzazione italiana nel Rio Grande del Sud 18751925. [s.l.; s.n.]. pp.311-318.

CINQUANTENARIO della colonizzazione italiana nel Rio Grande del Sud 18751925. 1925. [s.l.; s.n.].

COLBARI, Antonia. 1997. "Familismo e ética do trabalho: o legado dos imigrantes italianos para a cultura brasileira". Revista Brasileira de História, 17(34):53-74.

COSTA, Rovílio et alii. 1986. Imigração italiana no Rio Grande do Sul. Porto Alegre: EST/ Caxias do Sul: EDUCS.

CROCETTA, B. 1925. "Passato ed avvenire". In: Album do Cinquantenario della colonizzazione italiana nel Rio Grande del Sud 1875-1925. [s.1.; s.n.]. pp.455-462.

D'APREMONT, Bernardin \& GILLONAY, Bruno de. 1976. Comunidades indígenas, brasileiras e italianas no Rio Grande do Sul (1896-1915). Porto Alegre: EST/ Caxias do Sul: UCS.
DE BONI, Luis Alberto. 1980. "O catolicismo da imigração: do triunfo à crise". In: A. Lando et alii (org.), Migração \& colonização. Porto Alegre: Mercado Aberto. pp.234-255. 1983. A Itália e o Rio Grande do Sul. Relatório de autoridades italianas sobre a colonização em terras gaúchas. Porto Alegre: EST. . (org.). 1990. A presença italiana no Brasil. vol. 2. Porto Alegre: EST/ Torino: Fundação Giovanni Agnelli. 1996a. A presença italiana no Brasil. vol. 3. Porto Alegre: EST/ Torino: Fundação Giovanni Agnelli.

. 1996b. "O sucesso apesar do caos: os presidentes da província de São Pedro do RS a respeito da colonização (1869-1889)". In: A presença italiana no Brasil. vol. 3. Porto Alegre: EST/ Torino: Fundação Giovanni Agnelli. pp.91-125.

. \& COSTA, Rovílio. 1982. Os italianos do Rio Grande do Sul. 2.ed. Porto Alegre: EST/ Caxias: Universidade de Caxias.

DURKHEIM, Émile. 1996. As formas elementares da vida religiosa. São Paulo: Martins Fontes.

FAÉ, Walter José. 1975. Italianos no Rio Grande do Sul 1875-1975. Americana: Edições FOCAM.

FORNARI, Ernani. 1925. "Latinidade". In: Cinquantenario della colonizzazione italiana nel Rio Grande del Sud 1875-1925. [s.l.; s.n.]. p.323.

GOBBATO, Celeste. 1925. "Il colono italiano ed il suo contributo nello sviluppo dell 'industria riograndense". In: Cinquantenario della colonizzazione italiana nel Rio Grande del Sud 18751925. [s.l.; s.n.]. pp.195-242.

GROSSELI, Renzo Maria. 1987. Vencer ou morrer. Camponeses trentinos (venetos e lombardos) nas florestas brasileiras. Florianópolis: Editora da UFSC. 
HALBWACHS, Maurice. 1990. A memória coletiva. São Paulo: Vértice/ Editora Revista dos Tribunais.

HUTTER, Lucy Maffei. 1972. Imigração italiana em São Paulo (1880-1889). São Paulo: Instituto de Estudos Brasileiros.

LORENZONI, Julio. 1975. Memórias de um imigrante italiano. Porto Alegre: Sulina.

MACHADO, Paulo Pinheiro. 1999. A política de colonização do Império. Porto Alegre: EdUFRGS.

MARCON, Itálico. 1975. "À guisa de prefácio". In: J. Lorenzoni, Memórias de um imigrante italiano. Porto Alegre: Sulina. pp.9-10.

POZZOBON, Andréa. 1997. "Uma odisséia na América". In: Z. F. Pozzobon, Uma odisséia na América. Caxias do Sul: EDUCS. pp.17-307.

REVISTA Commemorativa Primeiro Centenário da Fundação da cidade de Santa Maria-RS. 1814-1914. S.L.S.d.

RIGHI, José Vicente et alii. 2001. Povoadores da Quarta Colônia. Porto Alegre: EST.

SANTIN, Silvino \& ISAIA, Antônio. 1990. Silveira Martins: patrimônio histórico-cultural. Porto Alegre: EST.

SANTIN, Silvino. 1986. A imigração esquecida. Porto Alegre: EST/ Caxias do Sul: EDUCS.

SEYFERTH, Giralda. 1990. Imigração e cultura no Brasil. Brasília: EdUnB. 1993. "Identidade camponesa e identidade étnica (um estudo de caso)". Anuário Antropológico, 91:31-63.
1997. "A assimilação dos imigrantes como questão nacional". Mana. Estudos de Antropologia Social, 3(1). Disponível em: http:www. scielo.org.br. Acesso em 2002.

SPONCHIADO, Padre Luiz. 1990. "A anágrafe de Nova Palma e os inícios da Colônia Silveira Martins". In: L. A. De Boni (org.), A presença italiana no Brasil. vol. 2. Porto Alegre: EST/ Torino: Fundação Giovanni Agnelli. pp. 425-446.

2001. "Os pioneiros da IV Colônia de Silveira Martins". In: A. Suliani (org.), Etnias e carisma. Porto Alegre: Edipucrs. pp.711-720.

SULIANI, Antônio (org.). 2001. Etnias e carisma. Porto Alegre: Edipucrs.

TRUDA, Francisco de Leonardo. 1925. "Linfluenza etnica, sociale ed economica della colonizzazione italiana nel Rio Grande del Sud". In: Cinquantenario della colonizzazione italiana nel Rio Grande del Sud 1975-1925. [s.l.; s.n.]. pp. 245-255

VESCIO, Luiz Eugênio. 2000. O crime do padre Sório. Tese de doutorado, Programa de Pós-graduação em História Social, São Paulo, Departamento de História, USP.

ZANINI, Maria Catarina Chitolina. 2005. "O Estado Novo e os descendentes de imigrantes italianos: entre feridas, fatos e interpretações". In: C. Dalmolin (org.), Mordaça verde e amarela. Santa Maria: Palotti. pp.113-128. 2006. Italianidade no Brasil meridional. A construção da identidade étnica na região de Santa Maria-RS. Santa Maria: EdUFSM. 


\section{Resumo}

Este artigo tem por objetivo analisar de que forma os migrantes italianos que se dirigiram para a região central do estado do Rio Grande do Sul em finais do século XIX conduziram a colonização local e quais as categorias sociais presentes nesse processo. Utilizarei como fonte as memórias escritas por dois imigrantes: Julio Lorenzoni (publicadas em 1975) e Andrea Pozzobon (publicadas em 1997), bem como o Álbum do Primeiro cinqüentenário da imigração italiana no estado, escrito em italiano e impresso em 1925. Efetuar uma análise antropológica das narrativas documentais dessa imigração é algo extremamente fértil para se compreender, também, a dinâmica contemporânea das reivindicações étnicas em nível local, que se sustentam na construção de uma origem baseada na ancestralidade italiana.

Palavras-chave: Italianidade, Colonização, Identidade étnica

\section{Abstract}

This article aims to analyze the form in which the Italian migrants who arrived in the central region of the state of Rio Grande do Sul at the end of the 19th century colonized the region and the social categories used in the process. As a source, I make use of memoirs written by two immigrants: Julio Lorenzoni (published in 1975) and Andrea Pozzobon (published in 1997), as well as the Album celebrating the First Fifty Years of Italian Immigration in the state, written in Italian and printed in 1925. An anthropological analysis of the written narratives documenting this immigration has also proven to be extremely fertile in terms of understanding the contemporary dynamic of ethnic claims at local level, based on the construction of an origin rooted in Italian ancestry.

Key words: Italianness, Colonization, Ethnic identity 